\title{
Destiny School of Business: Will leadership flaws continue to reduce employee morale?
}

\author{
Sifat Kamal, Shawkat Kamal \\ ${ }^{1}$ State University of Bangladesh \\ ${ }^{2}$ Green University of Bangladesh
}

\begin{abstract}
This case discusses several human resource management issues of a private university, as well as the problems arising in a particular department as a result of vague and opaque rules, double standards maintained in preserving discipline, and duplicity in performance evaluation. Turning a blind eye to the issues raised questions on the leadership abilities of the people at the top, and created confusion in the faculty members in their aspiration to grow with the institution. Even with changes in the leadership, no changes came to the institution that could really motivate the educators. Whoever came just either ventured to create a team of his/her own people, or tried to stay quietly so as not to come in harm's way. Most people with administrative power weren't willing to take responsibility for their actions, resulting in flawed or delayed decision making. Faculties were finding it difficult to motivate themselves to think their future with the University on a long term basis, and the management was apparently doing nothing to alleviate this problem.
\end{abstract}

Keywords: Motivation, Management, Business School, Bangladesh, Leadership, Organizational Behavior

It was a hot sunny afternoon in Dhaka, Bangladesh and Tanisha Fariel was waiting for her car to arrive at her workplace. Most of her colleagues had already left and Tanisha was sifting through her memories with Destiny School of Business (DSB) where she had been working for the last couple of years. The dreaded feeling was coming back, and she was feeling very low as she wondered whether the environment of the organization would ever change and she would get back to the old enthusiastic self that she was when she entered the organization. She surely hoped it would, but unfortunately she had little if any influence on that. The erratic and sometimes inexplicable decisions from the leadership of DSB over the last two years have had its toll on the employee morale in general, and it was the leadership's responsibility now to fix this problem.

\section{Destiny School Of Business}

Destiny School of Business was part of Destiny University, a midsized private university located at the center of Dhaka city. The business school started its journey in 2002 and had since been seeing a constant, albeit slow, growth in the number of students. Initially the school had little resources and was not very well known. But with time it could establish itself as a good destination for students who were seeking to pursue a business degree at an affordable cost. However, the management of the university expected the growth of DSB to be even better and hence appointed a vice chancellor who was specialized in business education. He had been looking after the business school for the last three years in addition to his role as a vice chancellor and took some important steps to take the school forward. However, the University recently appointed a Dean, Dr. Shuja Khondokar, to oversee the activities of the Business School. It was expected that this change in leadership will bring significant change in the quality of education and would also help increase the number of students in the MBA program.

\section{Tanisha Fariel}

Tanisha was a business graduate of the Institute of Business Administration (IBA) of Dhaka University. She completed both her BBA and MBA from IBA and by dint of her good results landed on a teaching job when she joined DSB two years ago. She had a short stint in the corporate world before joining DSB, but never felt very comfortable working in a corporate environment. So, she was really happy to join DSB and the process of recruitment and selection went smoothly. She was warmly welcomed by her colleagues and seniors, and DSB seemed to her to be the perfect choice to start a career in academia.

\section{The Illusion Starts Fading}

It did not take long for Tanisha to realize that the faculty members were at odds with the management of the organization, which was pretty much common in any private educational institution in the country. What she failed to realize was how deep set had the resentment been between the two parties. Tanisha couldn't help noticing the way her least cautious colleagues spoke ill of the management in hushed tones, but thought that 
maybe this was just one side of the coin. But eventually, getting in personal contact with different levels of management staff, she realized that the main feud was over money. Everything that would cost any amount of money (what doesn't?) would not only be questioned, but also the person initiating the expense vilified somehow, as well as the issues judged as of not much consequence.

Tanisha was having a chat with one of her peers once who she thought trustworthy, and asked for his opinion regarding the feud between the management and the members of the faculty. He told her that the faculty were more qualified than most of the management staff, and got a higher compensation and more respect from the community, which gave the staff an inferiority complex. Kaniz Kibriah, the owner responsible for heading the university had some people placed in different levels of management chiefly on the basis of loyalty and personal relation. And most of them probably knew in their heart that they were there not because of what they had done or accomplished, but because of whom they had known or had been related to. The obvious reaction to such a self-image had to be putting down others to keep themselves up. In this case, the scapegoat had to be all the members of the faculties irrespective of department or position. Since the owner was too busy to find things for how they really were, she only listened to and believed whatever her loyal staff told her. And she was very abrupt with accusations on many occasions against the faculty members. The loyal staffs convinced her that the teachers were overpaid and did not work enough to earn it.

Tanisha herself faced a serious lack of organizational support as a faculty member and found many reasons to feel demotivated. For a starter, there were no fixed dates for sending the salaries to the salary accounts. There was a date, though, which was seldom maintained. Since there hadn't been a counseling room, the faculty corner was frequented by students and many an awkward moment occurred between the students and teachers. Office supplies, adequate computers in good working order, and last but not the least, proper arrangement of classrooms were never a regular feature in the working environment of the business school.

\section{The Promotion And Other Controversies}

As a whole, this part seemed pretty vague to all the members of the faculty. According to the usual rules in the academia, the teachers progressed in their careers through tenure, publications, degrees, diplomas, or $\mathrm{PhDs}$; and the teachers in DBS were no different from those of other universities. But they were not given clear directions or guidance on how to proceed with the advancement of their careers, as they could not really understand how their performance was linked to an increment or a promotion. For example, when two lecturers with the required qualification for a promotion applied for the same position, one got it promptly while the other didn't get it without a lot of persuasion. Even after that the former got an increment while the latter didn't. Upon inquiries of the surprised teachers, word came from management that the position of a senior lecturer started with a pay scale which was less than the teacher was already getting due to inflationary adjustments. At this point a question could arise. Why had the former one been an exception? Why had he got an increment when the other didn't? This was more confusing than ever, and Tanisha was worried about the time when her turn would arrive.

The same went with employee recognition, which usually was supposed to lead to organizational advancement. But the management had seemed to concentrate more on making sure nobody broke the rules rather than identifying who outperformed the others. As a result, the evaluators had been blind to the individual efforts of the faculty members. So one may dare ask the most important question, "How did management understand who were better than the rest?" Well, it seemed that the faculty members who always praised themselves had always been revered by the staff and the body of administration alike, irrespective of the fact whether they deserved such respect and admiration. Does it answer the question? How could people be so blind and so stupid? And should Tanisha feel comfortable putting her future in the hands of these people?

The remuneration for the faculties was lower than other universities of similar standard or market position. When this was brought to the attention of the management, they tried not to budge, telling the affected that they had done nothing to deserve it. After a hard negotiation, the top management agreed to give one increment, which was by no way close to the proper inflationary adjustments.

\section{The Arrival And Departure Of Aolad Hossain}

Dr. Aolad Hossain was recruited through a head-hunting agency as the head of the department a year after Tanisha joined. All the faculty members were both curious and hopeful about their new head. Although initially he seemed cordial, soon he started making everybody's life difficult. He started by establishing ground rules for the faculty members, implying actions would be taking against faculty members unless they abided by those. He tried to make a committee for everything, which was silly and redundant. He was arrogant and often wouldn't show people proper respect, which got him disrespect in return. On top of that, he made derogatory comments about people without considering how they would feel. Tanisha realized that this man was destroying whatever was left of her department, and she wished that he would go away. He did, by the way, when he, in his 
pursuit of complete inertia, let some people handle sensitive information, which was not supposed to be available to them. When the incident came to light, they made him resign quietly.

\section{The Vice Chancellor And The Dean}

Like most other private universities in Bangladesh, department of Business was the biggest, which generated the lion's share of the revenues. But for some reason, in all these universities, the other, smaller departments tried to undermine Business department and somehow were encouraged by the management. Destiny was no different. Dr. Abrar Yousuf, the vice chancellor, a professor who had spent a significant part of his career teaching business students had a soft corner for this department. But he was always accused of siding with this department even when he had been doing what he thought was right. And for some reason, he was not always comfortable haggling with the owners. He was generally indecisive, and a bit frivolous, changing his mind about things very quickly, and agreeing to things in a half-hearted manner. Most of the times things would not be done unless and until directly instructed by him; and this proved to be an inefficient and ineffective way of running an organization. Some of the things that he approved of resulted in straight denial from the board, which also made him sensitive about making propositions in meetings with the top management.

Dr. Shuja Khondokar joined a few years after Dr. Yousuf had come to DBS. He was a man of actions, which was good for the organization as well as the department. But the problem was, as a new member, he had to work closely with people who at opportune moments would give him distorted facts. This resulted in him giving a couple of high profile faculty members (not belonging to the power players) a mild threat to keep them on their toes, indirectly accusing them of things they would never do. This alarmed the other neutral faculty members.

\section{The Web Of Collusion}

A few of the faculties who held some kind of administrative positions exploited the others by misusing their powers. They spared no opportunity to prove to their bosses that they were the only ones who had been doing anything worth mentioning in the department. Often such incidents occurred that some of these people's colleagues did something upon their request graciously expecting nothing in return, to find out later that credit and appreciation for that particular performance was given to somebody else. It's true that sometimes, in the attempts to get and/or stay in the limelight, some people think they are the reasons behind all the success. But this wasn't the case. None of the above mentioned people had been delusional about their position. They stole credit without shame or regret, and defamed their colleagues who they thought could become competition in future. On top of that, these people abused their position and distorted the messages that took the formal line of communication and distorted the real orders from the upper level and real requests from the low level of management. Interestingly, and not illogically, these people had really good relationship with each other. Each of them tried to establish the image what the others wanted to build of themselves. That's why the whole department was in a deadlock in many cases, of which the upper level of management was totally unaware.

\section{What Next?}

The department was running, albeit the fact that the employee morale was going down like a block of cement in the water. What came out as the result had been this - the people who stayed mostly had nowhere else to go or had been waiting for an opportunity to leave. Now Tanisha was wondering again. Why would the owners or the people who ran any organization do anything willingly to harm it? Had it been the case that they didn't care, or that they were clueless about the real scenario? In the latter case, are such people really worthy of any kind of leadership? There are conniving people everywhere, trying to use a shortcut to success, but the people who give it to them on a silver platter, wouldn't they bear any responsibility for being so blind or stupid? After all said and done, the final question comes - does Tanisha have a future in this organization? Can she really hope to grow with this organization unless and until some changes take place? 